\title{
Trichoderma species for biocontrol of soil-borne plant pathogens of pasture species
}

\author{
D.R.W. Kandula ${ }^{a^{*}}$, E.E. Jones ${ }^{b}$, A. Stewart ${ }^{\text {a† }}$, K.L. McLean ${ }^{\text {a }}$ and J.G. Hampton ${ }^{a}$ \\ ${ }^{a}$ Bio-Protection Research Centre, ${ }^{b}$ Faculty of Agriculture and Life Sciences, PO Box \\ 85084, Lincoln University, Lincoln 7647, New Zealand
}

\begin{abstract}
Soil-borne plant pathogens such as Rhizoctonia solani (Kuhn), Pythium ultimum (Trow) and Sclerotinia trifoliorum (Eriks) can reduce grass and forage legume establishment. The potential for biocontrol of these pathogens by Trichoderma fungi was evaluated. Following dual culture assays, nine Trichoderma isolates (five of $T$. atroviride and one each of T. hamatum, $T$. koningiopsis, $T$. viride and $T$. virens) were chosen for assessment in pot experiments. In the presence of $R$. solani, perennial ryegrass (Lolium perenne L.) emergence was increased by $60-150 \%$ by two isolates of $T$. atroviride and by $35-212 \%$ by the isolate of $T$. virens, with the increase depending on growing medium and amount of pathogen inoculum. Red clover (Trifolium pratense L.) emergence in the presence of $S$. trifoliorum was significantly increased by two $T$. atroviride isolates and the T. hamatum isolate. In the presence of $P$. ultimum, white clover (Trifolium repens L.) emergence was increased by $25-42 \%$ by one isolate of $T$. atroviride and the $T$. hamatum isolate. However, for all three pasture species, some Trichoderma isolates reduced seedling emergence. Seedling growth (shoot and root fresh weight/plant) of the three pasture species was significantly increased by one or more $T$. atroviride isolates. On the basis of these results for both disease reduction and growth promotion, four $T$. atroviride isolates were selected for field assessment as biocontrol agents of soilborne pathogens of pasture species.
\end{abstract}

Keywords: Rhizoctonia solani; Pythium ultimum; Sclerotinia trifoliorum . Dampingoff; seedling establishment

*Corresponding author. E-mail: diwakar.kandula@lincoln.ac.nz

Present Address:

$47{ }^{\dagger}$ Marrone Bio Innovations Inc., 2121 Second St, Davis, CA 95618, USA 


\section{Introduction}

Soil-borne plant pathogens can be major biological constraints to pasture establishment (Falloon, 1985; Skipp \& Watson, 1996) and production (Falloon \& Fletcher, 1983; O'Rourke et al., 2009). In New Zealand, soil-borne pathogens commonly-associated with diseases of grass and forage legume seedlings include Rhizoctonia solani (Kuhn), Pythium ultimum (Trow) (Skipp \& Watson, 1996) and Sclerotinia trifoliorum Eriks (Skipp \& Hampton, 1996). R. solani and $P$. ultimum can reduce establishment of grasses and legumes (Skipp \& Christensen 1989a,b; Waipara et al.,1996; Sarathchandra et al., 2000). In perennial ryegrass (Lolium perenne L.) these pathogens usually infect the seed or seedling prior to emergence (preemergence damping off - Falloon, 1985). In white (Trifolium repens L.) and red ( $T$. pratense L.) clovers, $S$. trifoliorum initially causes brown leaf lesions before infection spreads to the stems and shoots, eventually killing the plant (Harvey and Harvey 2009). However, data for seedling losses are not readily available, primarily because in the field they have been difficult to define and quantify as damage frequently results from complex interactions among several soil-borne pathogens (Skipp \& Watson, 1996).

While pasture seeds can be fungicide treated to combat damping-off (Charlton \& Stewart, 2000), the use of fungicides to control sclerotinia rot is not considered to be cost effective (Harvey and Harvey 2009), and while Falloon $(1980,1981)$ recommended fungicide seed treatment, Latch (1996) considered that it was uneconomic to use fungicides to control pathogens in New Zealand pastures. However, biocontrol may offer an alternative strategy for New Zealand's pastoral farmers, as Skipp and Hay (1993) and Waipara (2000) suggested that the soil-borne fungus Trichoderma may have potential for control of damping-off diseases in pasture. Commercial Trichoderma-based products are available for biological control of soil-borne diseases in vegetables (Stewart, 2001).

The development of new biocontrol products against plant diseases requires screening of a high number of candidate antagonists which have to fulfil many requirements to be commercially successful (Kohl et al., 2011). The objective of this research was to identify New Zealand Trichoderma isolates able to improve seedling establishment in the presence of soil-borne pathogens and/or enhance seedling growth of pasture species important to New Zealand, specifically perennial ryegrass and white and red clover.

\section{Materials and methods}

Screening of Trichoderma isolates.

One hundred Trichoderma isolates from the Bio-Protection Research Centre's collection were included in dual culture assays (Ghaffar, 1969) with pairings against three pathogens viz R. solani, P. ultimum and S. trifoliorum. Isolates of these 
pathogens were sourced from the Lincoln University microbial culture collection. Nine of these isolates which produced an antagonist ' $\mathrm{B}$ ' type interaction (growing margins of the two colonies meet, pathogen growth inhibited and/or overgrown by the Trichoderma isolate) or ' $D$ ' type interaction (pathogen inhibited at a distance leaving a zone of inhibition (Ghaffar, 1969)) were chosen for use in pot experiments. Five of these Trichoderma isolates (LU 132, LU 140, LU 584, LU 633, LU 634) were $T$. atroviride, and one each were T. hamatum (LU 740), T. koningiopsis (LU 713), T. viride (LU 644), and T. virens (LU 540).

Production and application of Trichoderma inoculum

Trichoderma isolates were grown in sterile wheat bran and peat. Seventy-five grams of wheat bran and $25 \mathrm{~g}$ of sieved peat were added to each of 18 (two flasks/isolate) $500 \mathrm{ml}$ flasks. The flasks were autoclaved at $121^{\circ} \mathrm{C}$ and $15 \mathrm{psi}$ for $20 \mathrm{~min}$ on two consecutive days. The sterile medium was inoculated with five colonised agar plugs/flask, taken from the actively growing edge of a 5 day-old Trichoderma colony. For all the pot experiments described next, $1 \mathrm{~g}$ of colonized wheat bran/peat for each Trichoderma isolate (approx. $2-3 \times 10^{8} \mathrm{cfu} / \mathrm{g}$ ) was added to $400 \mathrm{~g}$ of plant growing medium for each pot (see below) just prior to seed sowing. This gave a concentration of $1 \times 10^{6} \mathrm{cfu} / \mathrm{g}$ plant growing medium.

Preparation of pathogen inoculum

\section{Rhizoctonia solani}

Fifty grams of wetted wheat bran (2 parts bran: 1 part water) in each of six $250 \mathrm{ml}$ flasks was autoclaved at $121^{\circ} \mathrm{C}$ and 15 psi for 20 min on two consecutive days. Sterile wheat bran was inoculated with five colonised agar plugs taken from the actively growing edge of a 3-day-old $R$. solani colony grown on PDA in the dark. Each flask was incubated at $20^{\circ} \mathrm{C}$ in the dark for $12 \mathrm{~d}$.

\section{Sclerotinia trifoliorum}

S. trifoliorum was grown on sterile wheat grains. One hundred grams of wheat grain moistened with $240 \mathrm{ml}$ deionised water was added to each of three $500 \mathrm{ml}$ flasks which were then autoclaved at $121^{\circ} \mathrm{C}$ at $15 \mathrm{psi}$ for $20 \mathrm{~min}$ on two consecutive days. Once cool, the sterile wheat grains were inoculated with five colonised agar plugs taken from the actively growing edge of a 4-day-old $S$. trifoliorum culture grown on PDA at $20^{\circ} \mathrm{C}$ in the dark. The flasks were incubated at $20^{\circ} \mathrm{C}$ for $14 \mathrm{~d}$ in the dark.

\section{Pythium ultimum}

P. ultimum was grown on sterile white clover roots. One hundred grams of roots were added to each of two $250 \mathrm{ml}$ flasks. The flasks were autoclaved at $121^{\circ} \mathrm{C}$ and 15 psi for $20 \mathrm{~min}$. Once cool, the sterile roots in each flask were inoculated with five colonised agar plugs taken from the actively growing edge of a 3 day old culture grown on PDA. Flasks were then incubated at $20^{\circ} \mathrm{C}$ for $14 \mathrm{~d}$ in the dark. The $P$. 
ultimum oospore colonised roots were homogenised in a blender by adding an equal volume of deionised water.

\section{Pot experiments}

Rhizoctonia solani/perennial ryegrass

The first pot experiment used plant growthing medium (composted pine bark (80\%); pumice $1-4 \mathrm{~mm}$ grade (20\%); $5 \mathrm{~kg} \mathrm{~m}^{-3}$ slow release fertiliser comprising $1 \mathrm{~kg} \mathrm{~m}^{-3}$ horticultural lime, $1 \mathrm{~kg} \mathrm{~m}^{-3}$ hydraflo wetting agent, and $3 \mathrm{~kg} \mathrm{~m}^{-3}$ osmocote extract [16N-35P-10K]), with $400 \mathrm{~g}$ of this medium being placed in each pot. A preliminary experiment had determined that $2 \mathrm{~g} R$. solani colonised wheat bran added to each pot resulted in approximately $50 \%$ of the emerged perennial ryegrass seedlings damping off (Table 1), and this was the inoculum rate used in the subsequent experiments. There were 11 treatments, the nine Trichoderma isolates (Table 21 ) challenged by $R$. solani, a pathogen control and an uninoculated control. All treatments except the two controls were replicated four times, while each control treatment was replicated eight times. Forty perennial ryegrass seeds were sown in each pot at a depth of 5-6 mm. Pots were arranged in a completely randomized block design on tables in a glasshouse which was maintained at an average temperature of $20^{\circ} \mathrm{C}$ for the duration of the experiment. The pots were watered using overhead irrigation as required.

Fifteen days after sowing (DAS) seedling emergence was recorded. For each pot, at least one non-emerged seed or seedling was retrieved, surface sterilised in $1 \%$ $\mathrm{NaOCl}$ for 2 min followed by rinsing twice in sterile distilled water, and then plated onto PDA. In all cases $R$. solani grew from these non-emerged seeds or seedlings. At 8 weeks after sowing, all plants from each pot were carefully removed, washed to remove potting mix, dried between paper towels and fresh weight of roots and shoots was recorded.

For the second pot experiment, a Wakanui silt loam soil naturally infested with $R$. solani was sourced from Lincoln University. A preliminary experiment using three soil: pumice dilutions $(3: 1,2: 2,1: 3)$ showed the $1: 3$ dilution produced approximately $50 \%$ damping off of emerged seedlings, and this rate was used for the experiment. For each pot, $500 \mathrm{~g}$ soil (sieved to $2 \mathrm{~mm}$ ) and pumice mixture were used. Three Trichoderma isolates (LU 132, LU 140, LU 540, chosen based on the results in plant growth medium; Table 21) were assessed after having been prepared and added to the soil as previously described. There were nine treatments (Table $\underline{3} z$ ), as the three Trichoderma isolates were challenged in naturally infected soil, and also in the same soil inoculated with $R$. solani at the same rate as for the plant growth medium experiment described above. Each treatment was replicated ten times. Seed sowing, glasshouse environment and experimental design were also as previously described. Seedling emergence was recorded 21 DAS, and 7 weeks after sowing, all plants per pot were cut at ground level and shoot fresh weights were recorded.

\section{Sclerotinia trifoliorum / red clover}

The first pot experiment for this pathogen/host system used the plant growth medium mix described previously. Twelve grams of $S$. trifoliorum colonised wheat 
grains were thoroughly mixed with $400 \mathrm{~g}$ plant growth medium in each of 48 pots. A preliminary experiment had determined that this rate provided approximately $50 \%$ of plants with sclerotinia rot in the disease control treatment (Table 1). There were eleven treatments (Table 43); the nine Trichoderma isolates challenged by $S$. trifoliorum, a pathogen control and an uninoculated control, all of which were replicated eight times. Forty red clover seeds were sown in each pot at a depth of 5$6 \mathrm{~mm}$. Treatment randomisation and glasshouse conditions were as described previously for the perennial ryegrass experiments.

Twenty one DAS, seedling emergence was recorded and 7 weeks after sowing shoot weights and disease scores (where $1=$ no symptoms evident, to $5=$ seedling severely diseased) were recorded for each pot.

The second pot experiment used a Wakanui silt loam soil naturally infested with $S$. trifoliorum sourced from Lincoln University. A 3:1 soil-pumice dilution was used. There were two sets of treatments (Table $\underline{5} 4$ ) involving four Trichoderma isolates (LU 140, LU 634, LU 740, LU 644) chosen based on the results in plant growth medium (Table 43). The four isolates were challenged in naturally infected soil and also in field soil inoculated with $S$. trifoliorum at the same rate as for the plant growth medium experiment (described above). Each treatment was replicated eight times. Seed sowing, glasshouse environment and experimental design were also as previously described. Seedling emergence was recorded 21 DAS, and shoot weight and disease score recorded at 7 weeks after sowing.

\section{Pythium ultimum / white clover}

The first experiment used $400 \mathrm{~g}$ plant growth medium/pot to which $0.8 \mathrm{ml}$ inoculum was added and mixed thoroughly. This level was based on a preliminary experiment which determined that this rate of inoculum resulted in approximately $50 \%$ diseased seedlings (Table 1). The 11 treatments were the same as for the red clover experiment, except that the pathogen challenge was $P$. ultimum (Table $\underline{6} 5$ ). Each treatment was replicated ten times. Seed sowing, glasshouse environment, experimental design and assessments were as described for red clover (above).

\section{Growth promotion by Trichoderma}

For perennial ryegrass, red clover and white clover, the nine Trichoderma isolates were added to pathogen-free plant growth medium (Table $\underline{76}$ ) as previously described. The inoculum rate, seed sowing, glasshouse environment, experimental design and assessments were as described for the pathogen challenge experiments.

A second growth promotion experiment using only perennial ryegrass and three formulations of one Trichoderma isolate (LU 584) was also conducted in plant growth medium (Table 877). The three Trichoderma treatments were colonised wheat bran plus peat $\left(2.3 \times 10^{7} \mathrm{cfu} / \mathrm{g}\right)$, a seed coating $\left(1 \times 10^{7} \mathrm{cfu} / \mathrm{g}\right.$ seed $)$ and a proprietary granule supplied by AgResearch Ltd $\left(2.5 \times 10^{7} \mathrm{cfu} / \mathrm{g}\right.$ granule) applied to the plant growth medium at a rate equivalent to $30 \mathrm{~kg} / \mathrm{ha}$. Each treatment was replicated ten times. Seed sowing, glasshouse environment and experimental design were as 
previously described. Seedling emergence was recorded 15 DAS and shoot weights from each pot determined at 8 weeks.

\section{Statistical analysis}

All data were subjected to a one way ANOVA with a probability level of $\mathrm{P}<0.05$ used for mean separation using Fisher's unprotected LSD test.

\section{Results}

Disease Control

Rhizoctonia solani / perennial ryegrass

In the plant growth medium, emergence in the no pathogen control was $86 \%$ but the presence of the pathogen reduced emergence to $38 \%$ (Table 21). Three of the Trichoderma isolates (LU 132, LU 140 and LU 540) significantly increased emergence over that of the pathogen control (Table 21), but their emergence was lower than from that of the uninoculated control. However emergence for LU 584, LU 633, LU 740 and LU 713 was significantly lower than that of the pathogen control (Table 21). Shoot and root fresh weight per pot did not differ between the two controls, but LU 584 and LU 633 produced greater shoot fresh weights than the pathogen control (Table 21). Treatment with LU 584 and LU 633 also significantly increased shoot dry weight per pot compared with the control, but only LU 633 increased root weight per plant. LU 740 and LU 713 had lower root fresh weights per pot than the pathogen control. No post-emergence damping off of seedlings in any of the treatments was recorded.

In soil naturally infested by $R$. solani, seedling emergence was significantly lower (50\%) than that of the potting mix control or LU140 (both $80 \%$, Table $3 z A$ ). The other two isolates did not significantly increase emergence. When this field soil was inoculated with the pathogen, both LU 140 and LU 540 increased seedling emergence over that of the $R$. solani control (Table $32 \mathrm{~B}$ ). Shoot fresh weight per pot was increased by LU 140 and LU 540 incorporated into naturally infested field soil (Table $\underline{3} z A$ ), and all three isolates increased shoot fresh weight when the naturally infested soil was inoculated with $R$. solani (Table $32 \mathrm{~B}$ ). Shoot fresh weight per plant was not increased by any of the isolates in either soil type (Table $\underline{3} z \mathrm{~A}, \underline{3} z \mathrm{~B})$. All seedlings were healthy in all the treatments.

\section{Sclerotinia trifoliorum / red clover}

In plant growth medium ${ }_{L}$ seedling emergence was low for all treatments (range 42$61 \%$ ) and did not differ between the two controls (Table 43 ). One isolate, LU584 significantly increased emergence over that of the pathogen control. Five isolates (LU 140, LU 634, LU 740, LU 713, LU 644) increased shoot fresh weight per pot over that of the pathogen control, and one (LU 740) had a higher shoot weight per pot and per plant than the no pathogen control (Table 43). LU 140, LU 634, LU 740 and LU 644 all had higher shoot weights per plant than the pathogen control. All the isolates significantly reduced the disease score compared with the pathogen control, 
with LU 140, LU 634, LU 740 and LU 644 not differing significantly from the pathogen-free control.

In soil naturally infested with S. trifoliorum, seedling emergence was only $10 \%$, and while LU 140 and LU 634 had a significantly greater emergence, it was still only around $20 \%$ (Table $\underline{5} 4 \mathrm{~A}$ ). S. trifoliorum significantly reduced shoot fresh weight per pot compared with that of the plant growth medium control but none of the isolates increased shoot weight (per pot or per plant) over that of the field soil control. Disease score for all the isolates was significantly greater than that for the plant growth medium, but apart from LU 644, was significantly lower than that for the field soil control (Table $\underline{5} 4 \mathrm{~A}$ ). When $\mathrm{S}$. trifoliorum was inoculated into the naturally infested field soil, very few seedlings emerged (range 4 to 9 per pot, Table $\underline{5} 4 \mathrm{~B}$ ). LU 634 and LU 740 gave a small, but significant, increase in emergence, and LU 740 also increased shoot fresh weight per pot but not per plant (Table $\underline{5} 4 \mathrm{~B})$. Disease score was significantly reduced by all the isolates except LU 140 (Table $\underline{5} 4 \mathrm{~B})$.

\section{Pythium ultimum / white clover}

In plant growth medium, emergence was $88 \%$ for the no pathogen control but only $59 \%$ in the presence of the pathogen (Table $\underline{6}$ ). Only two isolates, LU 633 and LU 740 gave increased emergence in the presence of the pathogen. LU 634 increased shoot fresh weight per pot and per plant over that of the pathogen control, but this was still substantially less than that of the no pathogen control (Table $\underline{6} 5$ ). Two isolates (LU 634 and LU 740) significantly reduced the disease score compared with that of the pathogen control, but disease scores for the other seven isolates were not reduced (Table $\underline{6} 5$ ).

\section{Growth Promotion}

Four isolates (LU 634, LU 740, LU 713 and LU 644) significantly reduced perennial ryegrass seedling emergence from that of the control (Table $\underline{76}$ ), but the mean number of seedlings per pot only fell from 34 (control) to 30 or 31 (data not presented). LU 584 and LU 633 produced large increases (178 and 172\%) in shoot fresh weight per plant and also in root fresh weight per plant (100 and 86\%; Table 76).

Emergence of red and white clover seedlings was not affected by the presence of the Trichoderma isolates with the exception of LU 140 which slightly reduced white clover emergence (Table $\underline{7} 6$, from 36 down to 32 seedlings per pot). Similarly, shoot fresh weight per plant was not significantly affected by the isolates for both species, with the one exception of LU 584 which gave an increase in red clover shoot fresh weight per plant (Table $\underline{76}$ ).

Perennial ryegrass seedling emergence for the three $T$. atroviride LU584 application methods did not differ from that in the plant growth medium control, but only the wheat bran treatment increased shoot weight per plant (Table $\underline{8} 7$ ).

\section{Discussion}


Fungal pathogens present in New Zealand soils can kill seedlings of forage plants, thus causing poor establishment (Falloon, 1981, Skipp \& Watson, 1987). Initially this was demonstrated through experiments with fungicide seed treatments which improved establishment of ryegrasses (Lolium spp.) and red clover (T. pratense L.) (Falloon, 1980; Skipp et al., 1986). Skipp and Watson (1996) listed fungal pathogens of grass and forage legume species in New Zealand including $R$. solani, P. ultimum and $S$. trifoliorum, but noted that it was often difficult to define and quantify losses caused by these pathogens because more than one may be involved. Skipp et al. (1986) did record a 30\% reduction in red clover emergence in a field soil naturally infested with Pythium spp. (primarily P. ultimum). In the current plant growth medium experiments, $R$. solani reduced perennial ryegrass seedling emergence by $57 \%$, S. trifoliorum reduced red clover seedling emergence by $17 \%$, and $P$. ultimum reduced white clover seedling emergence by $31 \%$. As the pathogen inoculum levels added to the potting mix were chosen to produce approx. $50 \%$ seedling death, these results were as expected for perennial ryegrass and white clover, but lower than expected for red clover, although the pathogen did increase the disease score of emerged seedlings. However, in comparisons between seedling emergence of seeds sown into field soil known to contain the pathogens and those sown into sterile plant growth medium, inoculation with $R$. solani reduced perennial ryegrass emergence by $38 \%$ and inoculation with $S$. trifoliorum reduced red clover emergence by $78 \%$.

These results, and those of Skipp et al. (1986), were obtained from a glasshouse maintained at around $20^{\circ} \mathrm{C}$ where pots were regularly watered to avoid moisture stress. They are therefore somewhat removed from a field situation, where average $10 \mathrm{~cm}$ soil temperature at sowing in New Zealand in autumn and spring is from 8$14^{\circ} \mathrm{C}$ depending upon location (Hampton et al., 1987), and soil moisture contents may vary considerably. Such conditions exert more stress on seeds as germination may decrease and time to emergence increase as soil temperature decreases (Charlton et al., 1986), thus potentially allowing more time for pathogen attack. Pathogen activity will also be affected by soil temperature, but "cold preferring isolates" of $R$. solani are active at $13^{\circ} \mathrm{C}$ or less (Doornik, 1981) and S. trifoliorum can sporulate at $5-10^{\circ} \mathrm{C}$ (Raynal, 1990). Damping-off caused by $P$. ultimum can occur at $10^{\circ} \mathrm{C}$ or less (Martin \& Loper, 1999) and Falloon (1985) reported that Pythium spp. were more virulent at $7.5^{\circ} \mathrm{C}$ than at higher temperatures.

The success of seedling emergence of pasture species depends on many factors including seed lot quality, method and time of sowing, depth of sowing, soil type, previous cropping history, water availability, the presence of soil pests and the presence of soil-borne pathogens. Fungal soil-borne pathogens have the potential to cause significant establishment problems. The present study has demonstrated that in the presence of $R$. solani, perennial ryegrass seedling emergence was increased by $60-150 \%$ by two isolates of $T$. atroviride (LU 132, LU 140) and by $35-212 \%$ by the isolate of $T$. virens (LU 540). These increases depended on growing medium and inoculum level. The isolates of T. hamatum and T. viride, for which species Lewis et al. (1996), Bailey and Gilligan (1997) and Naeimi et al. (2010) had reported strains with activity against $R$. solani, did not increase seedling emergence. Lumsden and 
Locke (1989) increased Zinnia elegans plant stand by reducing damping off caused by $R$. solani following the addition of Gliocladium (Trichoderma) virens to the growing medium, while $T$. atroviride (formerly $T$. harzianum) biocontrol of $R$. solani has been reported by a number of authors (Lewis et al.,1996; Ha, 2010; Naeimi et al., 2010; URehman et al., 2012). U-Rehman et al. (2012) for example reported a $14 \%$ increase in cauliflower emergence and a $64 \%$ decrease in post-emergence damping off caused by $R$. solani for an isolate of $T$. atroviride. Isolates of $T$. atroviride have been shown to parasitise fungi such as $R$. solani (Grinyer et al., 2005) through the ability to release cell wall-degrading enzymes and antibiotics (Lorito et al., 1994, 1996).

The red clover emergence data recorded in the present study were poor, even for the plant growth medium control, primarily because a low vigour seed lot was used. Despite this, when challenged by S. trifoliorium, two isolates of T. atroviride (LU 584, 634) and the T. hamatum isolate (LU 740) gave a small but statistically significant increase in emergence. No reports are available for the use of Trichoderma spp. for biocontrol of $S$. trifoliorum, but all the isolates used here reduced seedling disease score, indicating bioactivity. Most research and commercial production has focussed on biocontrol of S. sclerotiorum (Verma et al., 2009). The mechanism by which $T$. atroviride isolates control this pathogen is likely to be through mycoparasitism of hyphae or sclerotia (Inbar et al., 1994; Jones \& Stewart, 2000). An isolate of $T$. hamatum has also been shown to reduce $S$. minor and S. sclerotiorum infection in lettuce and cabbage, respectively (Rabeendran et al., 2006; Jones et al., 2014) with the mechanism of action likely to be either through protection of the host rhizosphere from myceliogenic infection or induced resistance to protect from ascospore infection of above ground host tissues.

When challenged by P. ultimum, one isolate of T. atroviride (LU 633) and one of $T$. hamatum (LU 740) increased white clover seedling emergence by $25-42 \%$. A reduction in pre-and post-emergence damping off caused by $P$. ultimum has been previously reported for isolates of $T$. atroviride/harzianum (Lumsden et al., 1990; Chen et al., 2005; Siameto et al., 2010), and T. hamatum, T. viride and T. virens (Harman et al., 1981; Ha, 2010). Trichoderma spp. can aggressively attack and kill $P$. ultimum mycelia (Harman, 2000; Yang et al., 2004), and also produce antibiotic compounds which inhibit Pythium growth (Abdollahi et al., 2012) as was noted in the preliminary dual culture assays of the present study (Kandula, unpublished data). Trichoderma may also compete with this pathogen on the host surfaces or induce host resistance (Harman, 2000).

For perennial ryegrass, seedling emergence in the presence of $R$. solani was reduced by the T. hamatum (LU 740) and T. koningiopsis (LU 713) isolates, and in the absence of the pathogen by these two isolates plus the $T$. viride (LU 644) and one of the $T$. atroviride (LU 634) isolates. Trichoderma spp. produce numerous secondary metabolites with biological activity which can enhance plant growth (Harman et al., 2004). However, some strains can produce phytotoxins which can reduce plant growth. For example, strains of $T$. virens produce the phytotoxin viridiol, which when placed in close proximity to the seeds, can reduce emergence (Howell \& Stipanovic, 1994). This compound causes severe necrosis of the radicle and subsequent seedling 
death (Jones et al.,1988). The T. virens isolate used in the present study did not reduce seedling emergence. The reason(s) for the recorded reductions in emergence by the four isolates were not determined in this study.

In the presence of $R$. solani, two T. atroviride isolates (LU 584, LU 633) increased perennial ryegrass shoot fresh weight. In the absence of the pathogen, $T$. atroviride (LU 633) increased shoot fresh weight. Care should be exercised when interpreting pot experiment results for plant growth promotion by Trichoderma spp. Results expressed per pot may not reflect any growth promotion effects if the increase recorded can be explained by fewer seedlings and decreased competition for resources, thereby allowing increased individual seedling growth. For T. atroviride isolates LU 584 and LU 633, the number of emerged seedlings was lower than that of the $R$. solani control, indicating a growth promotion response. This was verified by the data for shoot and root fresh weight per seedling which were increased by these isolates in both the presence and absence of the pathogen. Trichoderma isolates producing increases in shoot fresh weight per plant in the presence of the pathogen for red and white clover differed from those which produced a similar response in perennial ryegrass viz T. atroviride (LU 140, LU 634), T. hamatum (LU 740), T. koningiopsis (LU 713) and T. viride (LU 644). In the absence of S. trifoliorum, only LU 584 increased shoot fresh weight per plant in red clover, and only T. hamatum (LU 740) increased white clover growth in the absence of the pathogen. Mechanisms for growth promotion are probably multiple (Harman et al., 2004) and may include reduced activity of deleterious root microflora, inactivation of toxic compounds in the root zone, solubilisation of nutrients in the soil, increased nutrient uptake, improved nutrient use efficiency, increased resistance to abiotic stresses and the production of auxin-like compounds (Harman et al., 2004). Although specific mechanisms for plant growth promotion were not assessed in the present study, it is likely that one or a combination of these mechanisms were responsible. As is the case in many studies, this effect was restricted to observations of improved plant growth with no indication of the possible mechanisms involved (Whipps, 2001).

The most useful Trichoderma strains for disease control and growth promotion are those that are rhizosphere-competent which have the ability to colonise and grow in association with plant roots (Harman, 2000). This requires delivery mechanisms which allow development of this close association between biocontrol agents and host plants. For the nursery industry, incorporation of Trichoderma into plant growing media before sowing achieves this result (Harman et al., 2004), but for field use, Trichoderma must be introduced at the time of seed sowing. Possible methods for this include seed coating or granules (Kandula et al. 2008), neither of which negatively affected perennial ryegrass seedling emergence or shoot fresh weight in the plant growth medium experiment.

As noted by Howell (2003), the production and activities of the enzymes and antibiotics associated with biocontrol and growth promotion by Trichoderma spp. are profoundly affected by soil temperature, the presence and activities of other soil microflora, the pathogen challenge, and soil types. While screening putative antagonists in pots containing test plants and pathogens probably increases the 
chances of selecting active agents (Knudsen et al., 1997), field studies are essential to confirm their efficacy. Using the Trichoderma activity summary data presented in Table 98, four T. atroviride isolates (LU 132, LU 140, LU 584, LU 633) were selected for field assessment as a mixture prototype product (Chohan et al., 2010) on the assumption that multiple biocontrol agents as mixtures will provide a greater chance of success in a field environment (Stewart, 2001).

\section{Acknowledgements}

This research was funded by New Zealand Ministry of Business, Innovation and Employment (Project LINX 0804). We thank Dr Jayanthi Swaminathan of AgResearch Ltd, Lincoln for provision of the proprietary granule, and Professor Richard Falloon, Bio-Protection Research Centre, for reviewing the manuscript.

\section{References}

Abdollahi, M., Ommati, F., \& Zaker, M. (2012). The in vitro efficacy of Trichoderma isolates against Pythium aphanidermatum, the causal agent of sugar beet root rot. J Research Agr Sci, 8, 79-87.

Bailey, D. J., \& Gilligan, C. A. (1997). Biological control of pathozone behaviour and disease dynamics of Rhizoctonia solani by Trichoderma viride. New Phytologist, 136, 359-367.

Charlton, D., \& Stewart, A. (2000). Pasture and Forage Plants for New Zealand. Grassland Research and Practice Series No. 8, New Zealand Grassland Association, Palmerston North, 74pp.

Charlton, J. F. L., Hampton, J. G., \& Scott, D. J. (1986) Temperature effects on germination of New Zealand herbage grasses. Proceedings of New Zealand Grassland Association, 47, 165-172.

Chen, J., Harman, G. E., Comis, A., \& Cheng G. W. (2005). Proteins related to the biocontrol of Pythium damping-off in maize with Trichoderma harzianum Rifai. Journal of Integrative Plant Biology, 47, 988-997.

Chohan, P., Kandula, D. R. W., Stewart, A., \& Hampton, J.G. (2010). Biological control of Rhizoctonia solani in perennial ryegrass using Trichoderma atroviride isolates. Proceedings of the $6^{\text {th }}$ Australasian Soilborne Diseases Symposium, 35 .

Doornik, A. W. (1981). Temperature dependence of the pathogenicity of several isolates of Rhizoctonia solani in some bulb crops as an intrinsic property of the isolate. Netherlands Journal of Plant Pathology, 87, 139-147.

Falloon, R. E. (1980). Seedling emergence responses in ryegrass (Lolium spp.) to fungicide seed treatments. New Zealand Journal of Agricultural Research, 23, 385-391. 
Falloon, R. E. (1981). Fungicide seed treatment to improve establishment of ryegrasses and other forage plants. Proceedings of the $34^{\text {th }}$ New Zealand Weed and Pest Control Conference, 43-47.

Falloon, R. E. (1985). Fungi pathogenic to ryegrass seedlings. Plant and Soil, 86, 7986.

Falloon, R. E., \& Fletcher, R. H. (1983). Increased herbage production from perennial ryegrass following fungicide seed treatment. New Zealand Journal of Agricultural Research, 26, 1-5.

Ghaffar, A. (1969). Biological control of white rot of onion. I. Interactions of soil micro-organisms with Sclerotinia cepivorum Berk. Mycopathologia et Mycologia Applicata, 38, 101-111.

Grinyer, J., Hunt, S., McKay, M., Herbert, B. R., \& Nevalainen, H. (2005). Proteomic response of the biological control fungus Trichoderma atroviride to growth on the cell walls of Rhizoctonia solani. Current Genetics, 47, 381-388.

Ha, T. N. (2010). Using Trichoderma species for biological control of plant pathogens in Vietnam. J ISSAAS, 16, 17-21.

Hampton, J. G., Charlton, J. F. L., Bell, D.D., \& Scott, D.J. (1987). Temperature effects on the germination of herbage legumes in New Zealand. Proceedings of the New Zealand Grasslands Association, 48,177-183.

Harman, G. E. (2000). Myths and dogmas of biocontrol: changes in perception derived from research on Trichoderma harzianum T-22. Plant Disease, 84, 377-393.

Harman, G. E., Chet, I., \& Baker, R. (1981). Factors affecting Trichoderma hamatum applied to seeds as a biocontrol agent. Phytopathology, 71, 569-572.

Harman, G. E., Howell, C.V., Viterbo, A., Chet, I., \& Lorito, M. (2004). Trichoderma species - opportunistic, avirulent plant symbionts. Nature Review Microbiol 2, 43-56.

Harvey, I. C., \& Harvey, B. M. (2009). Pasture Diseases in New Zealand. BioProtection Research Centre, Lincoln University, Lincoln, 144p.

Howell, C. R. (2003). Mechanisms employed by Trichoderma species in the biological control of plant diseases: The history and evolution of current concepts Plant Disease, 87, 4-10. 
Howell, C. R., \& Stipanovic, R. D. (1994). Effect of sterol biosynthesis inhibitors on phytotoxin (viridiol) production by Glioclaldium virens in culture. Phytopathology, 84, 969-972.

Inbar, J., Abramsky, M., Cohen, D., \& Chet, I. (1994). Plant growth enhancement and disease control by Trichoderma harzianum in vegetable seedlings grown under commercial conditions. European Journal of Plant Pathology, 100, 337-346.

Jones, E. E., Rabeendran, N., \& Stewart, A. (2014). Biocontrol of Sclerotinia sclerotiorum infection of cabbage by Coniothyrium minitans and Trichoderma spp. Biocontrol Science and Technology, 24, 1363-1382.

Jones, E. E., \& Stewart, A. (2000). Selection of mycoparasites of sclerotia of Sclerotinia sclerotiorum isolated from New Zealand soils. New Zealand Journal of Crop and Horticultural Science, 28, 105-114.

Jones, R.W., Lanini, W. T., \& Hancock, J. G. (1988). Plant growth response to the phytotoxin viridiol produced by the fungus Gliocladium virens. Weed Science, 36, 683-687.

Kandula, D. R. W., Stewart, A., McDermid, J., Gale, D., Swaminathan, J. (2008). Bioinoculant formulations for enhanced seedling emergence and pasture growth. In: McGill, R \& Rowarth, J. S. (eds). Seeds for Futures, Agronomy Society of New Zealand Special Publication No. 13; Grassland Research and Practice Series No. 14, Palmerston North, New Zealand, pp 147-148

Knudsen, I. M. B., Hockenhull, J., Jensen, D. F., Gerhardson, B., Hokeberg, M., Tahvonen, R., Teperi, E., Sundheim, L., \& Henriksen, B. (1997). Selection of biological control agents for controlling soil and seed-borne diseases in the field. European Journal of Plant Pathology, 103, 775-784.

Kohl, J., Postma, J., Nicot, P., Ruocco, M., \& Blum, B. (2011). Stepwise screening of micro-organisms for commercial use in biological control of plant-pathogenic fungi and bacteria. Biological Control, 57, 1-12.

Latch, G. C. M. (1996). Overview of New Zealand agriculture and pasture pathology. In: Chakraborty S et al. (eds), Pasture and Forage Crop Pathology, ASA, CSSA, SSSA, Madison, Wisconsin, pp 22-32

Lewis, J. A., Lumsden, R. D., \& Locke, J. C. (1996). Biocontrol of damping-off diseases caused by Rhizoctonia solani and Pythium ultimum with alginate prills of Gliocladium virens, Trichoderma hamatum and various food bases. Biocontrol Science and Technology, 6, 163-174.

Lorito, M., Hayes, C. K., di Petro, A., Woo, S. L., \& Harman, G. E.(1994). Purification, characterization and synergistic activity of a glucan $1,3-\beta$-glucosidase and an 
$N$-acetyl- $\beta$-D-glucosaminidase from Trichoderma harzianum. Phytopathology, 84, 398-405.

Lorito, M., Farkas, V., Rebuffat, S., Bodo, B., \& Kubicek, C. P. (1996). Cell wall synthesis is a major target of mycoparasitic antagonism by Trichoderma harzianum. Journal of Bacteriology, 178, 6382-6385.

Lumsden, R. D., \& Locke, J.C. (1989). Biological control of damping-off caused by Pythium ultimum and Rhizoctonia solani with Gliocladium virens in soilless mix. Phytopathology, 79, 361-366.

Lumsden, R. D., Carter, J. P., Whipps, J. M., \& Lynch, J. M. (1990). Comparison of biomass and viable propagule measurements in the antagonism of Trichoderma harzianum against Pythium ultimum. Soil Biology and Biochemistry, 22, 187-194.

Martin, F. N., \& Loper, J. E. (1999). Soilborne diseases caused by Pythium spp.: ecology, epidemiology and prospects for biological control. Critical Review of Plant Sciences, 18, 111-181.

Naeimi, S., Okhovvat, S. M., Javan-Nikkhah, M., Vagvolgyi, C., Khosravi, V., \& Kredics, L. (2010). Biological control of Rhizoctonia solani AG1-1A, the causal agent of rice sheath blight with Trichoderma strains. Phytopathologia Mediterranea, 49, 287-300.

O’Rourke, T. A., Scanlon, T. T., Ryan, M. H., Wade, L. J., McKay, A. C., Riley, I.T., Li, H., Sivasithamparam, K., \& Barbetti, M. J. (2009) Severity of root rot in mature subterranean clover and associated fungal pathogens in the wheatbelt of Western Australia. Crop and Pasture Science, 60, 43-50.

Rabeendran, N., Jones, E. E., Moot, D., \& Stewart, A. (2006). Biocontrol of Sclerotinia lettuce drop by Coniothyrium minitans and Trichoderma species. Biological Control, 39, 352-362.

Raynal, G. (1990). Kinetics of the ascospore production of Sclerotinia trifoliorum Eriks in growth chamber and under natural climatic conditions. Practical and epidemiological incidence. Agronomie, 10, 561-572.

Rehman, S., Lawrence, R., Kumar, E. J., \& Badri, Z. A. (2012). Comparative efficacy of Trichoderma viride, $T$. harzianum and carbendazim against damping-off disease of cauliflower caused by Rhizoctonia solani Kuehn. Journal of Biopesticides, 5, 23-27.

Sarathchandra, S. U., Watson, R. N., Skipp, R. A., Burch, G., Brown, J. A., \& Cox, N. R. (2000). Microbial pathogens and plant parasitic nematodes in pastures with declining vigour. New Zealand Journal of Agricultural Research, 43, 549-558. 
Siameto, E. N., Okoth, S., Amugune, N. O., \& Chege, N. C. (2010). Antagonism of Trichoderma harzianum isolates on soilborne plant pathogenic fungi from Embu District, Kenya. Journal of Yeast and Fungal Research, 1, 47-54.

Skipp, R. A., \& Christensen, M. J. (1989a) Fungi invading roots of perennial ryegrass (Lolium perenne L.) in pasture. New Zealand Journal of Agricultural Research, 32, 423-431.

Skipp, R. A., \& Christensen, M. J. (1989b) Host specificity of root-invading fungi from New Zealand pasture soils. Australasian Plant Pathology, 18, 101-103.

Skipp, R. A., Christensen, M. J., \& Biao, N. Z. (1986). Invasion of red clover (Trifolium pratense) roots by soilborne fungi. New Zealand Journal of Agricultural Research, 29, 305-313.

Skipp, R. A., \& Hampton, J. G. (1996). Fungal and bacterial diseases of pasture plants in New Zealand. In: Chakraborty S et al. (eds). Pasture and Forage Crop Pathology, ASA, CSSA, SSSA, Madison, Wisconsin, pp 213-236.

Skipp, R. A., \& Hay, F. S. (1993). Screening for biocontrol agents of root pathogens of pasture legumes. Proceedings of the XVII International Grassland Congress, pp 936-937.

Skipp, R. A., \& Watson, R. N. (1987). Pot experiments with pasture soils to detect soilborne pathogens of white clover and lucerne, and effects of field application of fungicides. New Zealand Journal of Agricultural Research, 30, 85-93.

Skipp, R. A., \& Watson, R. N. (1996). Disease complexes in New Zealand pastures. In: Chakraborty $S$ et al. (eds). Pasture and Forage Crop Pathology, ASA, CSSA, SSSA, Madison, Wisconsin, pp 429-451.

Stewart, A. (2001). Commercial biocontrol - reality or fantasy? Australasian Plant Pathology, 30, 127-131.

Verma, M., Brar, S. K., Tyagi, R. D., Surampalli, R. Y., \& Valero, J. R. (2007). Antagonistic fungi, Trichoderma spp.: panoply of biological control. Journal of Biochemical Engineering, 37, 1-20.

Waipara, N. W. (2000). Biodiversity of Trichoderma species in agricultural soils and their potential use as seed coat amendments for the biocontrol of soilborne plant pathogens (Abstract). Proceedings of the $53^{\text {rd }}$ New Zealand Plant Protection Conference, 450.

Waipara, N. W., Di Menna, M. E., Cole, A. L. J., \& Skipp, R. A. (1996) Potential pathogenicity of pasture plant root-colonising fungi to seedlings of legumes 
and grasses. Proceedings of the $49^{\text {th }}$ New Zealand Plant Protection Conference, 49, 212-215.

703

Whipps, J. M. (2001). Microbial interactions and biocontrol in the rhizosphere. Journal of Experimental Botany, 52, 487-511.

Yang, Y., Chang, K.F., Hwang, S. F., Callan, N. W., Howard, R. J., \& Blade, S.F. (2004). Biological control of Pythium damping-off in Echinacea angustifolia with Trichoderma species. Journal of Plant Disease Protection III, 126-136. 
Table 1. Effect of different inoculum concentrations (g or $\mathrm{mL} /$ pot in $400 \mathrm{~g}$ plant growth medium) of three different root pathogens on seedling emergence of three different pasture species in experiments to determine inoculum thresholds.

\begin{tabular}{|c|c|c|c|c|c|}
\hline \multicolumn{2}{|c|}{$\begin{array}{l}\text { Rhizoctonia solani }{ }^{\text {a }} / \\
\text { Perennial ryegrass }\end{array}$} & \multicolumn{2}{|c|}{$\begin{array}{c}\text { Sclerotinia trifoliorum }{ }^{\mathrm{b}} / \\
\text { Red clover }\end{array}$} & \multicolumn{2}{|c|}{$\begin{array}{c}\text { Pythium ultimum }{ }^{\mathrm{c}} / \mathrm{I} \\
\text { White clover }\end{array}$} \\
\hline $\begin{array}{l}\text { Inoculum } \\
\text { concentration } \\
\text { g/pot }\end{array}$ & $\begin{array}{l}\text { Seedling } \\
\text { emergence }^{d} \\
(\%)\end{array}$ & $\begin{array}{l}\text { Inoculum } \\
\text { concentration } \\
\text { g/pot }\end{array}$ & $\begin{array}{l}\text { Seedling } \\
\text { emergence }^{d} \\
(\%)\end{array}$ & $\begin{array}{l}\text { Inoculum } \\
\text { concentration } \\
\mathrm{ml} / \text { pot }\end{array}$ & $\begin{array}{l}\text { Seedling } \\
\text { emergence }{ }^{d} \\
(\%)\end{array}$ \\
\hline 0 & $90(5.4)$ & 0 & $79(6.9)$ & 0 & $91(4.8)$ \\
\hline 1 & $73(5.5)$ & 3 & $70(8.9)$ & 0.4 & 77 (14.8) \\
\hline 2 & 52 (11.1) & 6 & $62(8.9)$ & 0.8 & $51(7.5)$ \\
\hline 4 & $28(4.3)$ & 12 & $51(5.9)$ & 1.6 & $23(10.6)$ \\
\hline 8 & $11(5.5)$ & 24 & $20(7.4)$ & 3.2 & $7(4.3)$ \\
\hline
\end{tabular}

${ }^{\text {a }}$ R. solani colonised wheat-bran; ${ }^{b}$ S. trifoliorum colonised wheat grains; ${ }^{\text {chomogenised roots }}$ colonised with $P$. ultimum oospores; ${ }^{\mathrm{d}} 40$ seeds sown/pot. Mean values of four replicates are shown with standard deviation in parenthesis.

Table 2. Effect of nine Trichoderma isolates on perennial ryegrass seedling emergence and shoot fresh weight and root dry weight when grown in plant growth medium inoculated with Rhizoctonia solani.

\begin{tabular}{|c|c|c|c|c|c|}
\hline \multirow[t]{2}{*}{ Treatment } & \multirow{2}{*}{$\begin{array}{l}\text { Number of } \\
\text { seedlings } \\
\text { emerged }^{\mathrm{a}}\end{array}$} & \multicolumn{2}{|c|}{ Shoot weight } & \multicolumn{2}{|c|}{ Root weight } \\
\hline & & g/pot & $\mathrm{g} /$ plant & $\mathrm{g} / \mathrm{pot}$ & $\mathrm{g} /$ plant \\
\hline Control (no pathogen) & 35 & 8.0 & 0.23 & 3.9 & 0.11 \\
\hline Control (+ R. solani) & 15 & 5.7 & 0.38 & 2.6 & 0.17 \\
\hline LU 132 & 29 & 9.2 & 0.32 & 4.2 & 0.14 \\
\hline LU 140 & 28 & 8.1 & 0.29 & 3.2 & 0.11 \\
\hline LU 584 & 6 & 11.3 & 2.06 & 1.8 & 0.27 \\
\hline LU 633 & 6 & 15.8 & 2.84 & 3.0 & 0.48 \\
\hline LU 634 & 10 & 4.5 & 0.44 & 1.8 & 0.18 \\
\hline LU 740 & 3 & 2.1 & 0.50 & 0.6 & 0.13 \\
\hline LU 713 & 4 & 2.0 & 0.32 & 0.8 & 0.10 \\
\hline LU 540 & 27 & 7.4 & 0.27 & 3.7 & 0.14 \\
\hline LU 644 & 12 & 6.5 & 0.56 & 2.8 & 0.23 \\
\hline \multicolumn{6}{|l|}{$\operatorname{LSD}(P<0.05)$} \\
\hline Between isolates & 3.3 & 2.7 & 0.35 & 1.19 & 0.09 \\
\hline Isolates vs control & 4.5 & 3.7 & 0.47 & 1.61 & 0.12 \\
\hline Between controls & 4.7 & 3.8 & 0.49 & 1.69 & 0.13 \\
\hline
\end{tabular}


Table 3. Effect of three Trichoderma isolates on perennial ryegrass seedling emergence and shoot fresh weight when grown in field soil containing (A) natural Rhizoctonia solani infestation and (B) natural infestation plus inoculated infestation.

\begin{tabular}{|c|c|c|c|}
\hline \multirow[t]{2}{*}{ Treatment } & \multirow{2}{*}{$\begin{array}{l}\text { Number of } \\
\text { seedlings } \\
\text { emerged }^{\text {a }}\end{array}$} & \multicolumn{2}{|c|}{ Shoot weight } \\
\hline & & g/pot & g/plant \\
\hline \multicolumn{4}{|l|}{ A. } \\
\hline Control (plant growth medium) & $32 \mathrm{c}$ & $12.2 \mathrm{c}$ & $0.38 \mathrm{~b}$ \\
\hline Control (field soil) & $20 a b$ & $3.5 \mathrm{a}$ & $0.18 \mathrm{a}$ \\
\hline LU 132 & $18 \mathrm{a}$ & $4.1 \mathrm{ab}$ & $0.23 a b$ \\
\hline LU 140 & $32 \mathrm{c}$ & $5.3 \mathrm{~b}$ & $0.17 \mathrm{a}$ \\
\hline LU 540 & $27 \mathrm{bc}$ & $4.9 \mathrm{~b}$ & $0.22 \mathrm{a}$ \\
\hline $\operatorname{LSD}(P<0.05)$ & 7.1 & 1.3 & 0.13 \\
\hline \multicolumn{4}{|l|}{ B. } \\
\hline Control (field soil $+R$. solani) & $8 a$ & $1.8 \mathrm{a}$ & $0.20 \mathrm{a}$ \\
\hline LU 132 & $13 a b$ & $3.8 \mathrm{~b}$ & $0.30 \mathrm{a}$ \\
\hline LU 140 & $20 \mathrm{bc}$ & $4.9 \mathrm{bc}$ & $0.32 \mathrm{a}$ \\
\hline LU 540 & $25 \mathrm{c}$ & $5.8 \mathrm{c}$ & $0.24 \mathrm{a}$ \\
\hline $\operatorname{LSD}(P<0.05)$ & 7.3 & 1.6 & 0.17 \\
\hline
\end{tabular}

a out of 40 seeds sown per pot

Mean values followed by a different letter in the columns indicate significant differences according to Fisher's unprotected LSD test.

Table 4. Effect of nine Trichoderma isolates on red clover seedling emergence, shoot fresh weight and disease score when grown in plant growth medium inoculated with Sclerotinia trifoliorum.

\begin{tabular}{lllll}
\hline Treatment & Number of & \multicolumn{2}{l}{ Shoot weight } & Disease Score $^{\mathrm{b}}$ \\
& seedlings emerged & $\mathrm{g} /$ pot & $\mathrm{g} /$ plant & \\
\hline Control (no pathogen) & $23 \mathrm{bc}$ & $8.8 \mathrm{de}$ & $0.38 \mathrm{bc}$ & $1.0 \mathrm{a}$ \\
Control (+ S. trifoliorum) & $19 \mathrm{ab}$ & $3.6 \mathrm{a}$ & $0.19 \mathrm{a}$ & $3.0 \mathrm{~d}$ \\
LU 132 & $21 \mathrm{abc}$ & $4.5 \mathrm{ab}$ & $0.23 \mathrm{a}$ & $1.8 \mathrm{bc}$ \\
LU 140 & $22 \mathrm{bc}$ & $7.9 \mathrm{~cd}$ & $0.38 \mathrm{bc}$ & $1.1 \mathrm{a}$ \\
LU 584 & $25 \mathrm{c}$ & $5.0 \mathrm{ab}$ & $0.20 \mathrm{a}$ & $2.1 \mathrm{c}$ \\
LU 633 & $17 \mathrm{a}$ & $5.0 \mathrm{ab}$ & $0.30 \mathrm{ab}$ & $2.0 \mathrm{c}$ \\
LU 634 & $21 \mathrm{abc}$ & $10.6 \mathrm{ef}$ & $0.51 \mathrm{~cd}$ & $1.1 \mathrm{a}$ \\
LU 740 & $23 \mathrm{bc}$ & $11.6 \mathrm{f}$ & $0.53 \mathrm{~d}$ & $1.1 \mathrm{a}$ \\
LU 713 & $21 \mathrm{abc}$ & $6.3 \mathrm{bc}$ & $0.30 \mathrm{ab}$ & $2.3 \mathrm{c}$ \\
LU 540 & $21 \mathrm{abc}$ & $4.5 \mathrm{ab}$ & $0.22 \mathrm{a}$ & $2.1 \mathrm{c}$ \\
LU 644 & $20 \mathrm{ab}$ & $8.3 \mathrm{~cd}$ & $0.43 \mathrm{bcd}$ & $1.3 \mathrm{ab}$ \\
\hline LSD $(P<0.05)$ & 4.5 & 2.2 & 0.14 & 0.6 \\
\hline
\end{tabular}

a out of 40 seeds sown per pot

${ }^{b}$ where $1=$ no evidence of disease and 5 = severely diseased

Mean values followed by a different letter in the columns indicate significant

differences according to Fisher's unprotected LSD test. 
Table 5. Effect of four Trichoderma isolates on red clover seedling emergence, shoot fresh weight and disease score when grown in field soil containing (A) natural Sclerotinia trifoliorum infestation and (B) natural infestation plus inoculated infestation.

\begin{tabular}{|c|c|c|c|c|}
\hline \multirow[t]{2}{*}{ Treatment } & \multirow{2}{*}{$\begin{array}{l}\text { Number of } \\
\text { seedlings } \\
\text { emerged }^{\mathrm{a}}\end{array}$} & \multicolumn{2}{|c|}{ Shoot weight } & \multirow[t]{2}{*}{ Disease Score ${ }^{b}$} \\
\hline & & g/pot & g/plant & \\
\hline \multicolumn{5}{|l|}{ A. } \\
\hline Control (plant growth medium) & $19 \mathrm{c}$ & $17.1 \mathrm{c}$ & $0.90 a b$ & $1.0 \mathrm{a}$ \\
\hline Control (field soil) & $4 a$ & $4.3 a b$ & $1.08 a b$ & $3.8 \mathrm{~d}$ \\
\hline LU 140 & $9 \mathrm{~b}$ & $7.1 \mathrm{~b}$ & $0.78 a b$ & $2.5 \mathrm{bc}$ \\
\hline LU 634 & $8 \mathrm{~b}$ & $6.4 a b$ & $0.80 a b$ & $2.6 \mathrm{bc}$ \\
\hline LU 740 & $7 a b$ & $7.5 \mathrm{~b}$ & $1.07 \mathrm{~b}$ & $2.3 \mathrm{~b}$ \\
\hline LU 644 & $6 a b$ & $3.8 \mathrm{a}$ & $0.63 a$ & $3.3 \mathrm{~cd}$ \\
\hline $\operatorname{LSD}(P<0.05)$ & 3.5 & 3.2 & 0.39 & 0.8 \\
\hline \multicolumn{5}{|l|}{ B. } \\
\hline $\begin{array}{l}\text { Control (field soil + } \\
\text { S. trifoliorum) }\end{array}$ & $4 a$ & $2.8 \mathrm{a}$ & $0.70 \mathrm{a}$ & $4.1 \mathrm{c}$ \\
\hline LU 140 & 4 a & $3.9 a b$ & $0.97 a$ & $3.2 \mathrm{bc}$ \\
\hline LU 634 & $9 \mathrm{~b}$ & $6.1 \mathrm{ab}$ & $0.67 a$ & $2.6 a b$ \\
\hline LU 740 & $9 \mathrm{~b}$ & $6.7 \mathrm{~b}$ & $0.74 \mathrm{a}$ & $2.0 \mathrm{a}$ \\
\hline LU 644 & $8 a b$ & $5.5 a b$ & $0.69 \mathrm{a}$ & $2.6 a b$ \\
\hline LSD $(P<0.05)$ & 4.4 & 3.4 & 0.49 & 0.9 \\
\hline
\end{tabular}

${ }^{a}$ out of 40 seeds sown per pot

${ }^{b}$ where $1=$ no evidence of disease and 5 = severely diseased

Mean values followed by a different letter in the columns indicate significant

differences according to Fisher's unprotected LSD test. 
Table 6. Effect of nine Trichoderma isolates on white clover seedling emergence, shoot fresh weight and disease score when grown in plant growth medium inoculated with Pythium ultimum.

\begin{tabular}{cllll}
\hline Treatment & Number of & \multicolumn{2}{l}{ Shoot Weight } & Disease Score $^{\mathrm{b}}$ \\
& seedlings emerged & g/pot & $\mathrm{g} /$ plant & \\
\hline Control (no pathogen) & $35 \mathrm{e}$ & $11.9 \mathrm{e}$ & $0.34 \mathrm{~d}$ & $1.0 \mathrm{a}$ \\
Control (P. ultimum) & $24 \mathrm{ab}$ & $3.2 \mathrm{abc}$ & $0.13 \mathrm{ab}$ & $3.3 \mathrm{de}$ \\
LU 132 & $25 \mathrm{abc}$ & $3.7 \mathrm{abcd}$ & $0.13 \mathrm{ab}$ & $3.0 \mathrm{~cd}$ \\
LU 140 & $21 \mathrm{a}$ & $1.4 \mathrm{a}$ & $0.07 \mathrm{a}$ & $4.0 \mathrm{e}$ \\
LU 584 & $29 \mathrm{bcd}$ & $3.1 \mathrm{ab}$ & $0.10 \mathrm{ab}$ & $3.2 \mathrm{de}$ \\
LU 633 & $30 \mathrm{cde}$ & $4.1 \mathrm{abcd}$ & $0.14 \mathrm{ab}$ & $2.8 \mathrm{bcd}$ \\
LU 634 & $26 \mathrm{abc}$ & $6.4 \mathrm{~d}$ & $0.25 \mathrm{c}$ & $2.1 \mathrm{bc}$ \\
LU 740 & $34 \mathrm{de}$ & $5.9 \mathrm{~cd}$ & $0.18 \mathrm{bc}$ & $1.9 \mathrm{ab}$ \\
LU 713 & $27 \mathrm{bc}$ & $3.2 \mathrm{abc}$ & $0.11 \mathrm{ab}$ & $3.3 \mathrm{de}$ \\
LU 540 & $24 \mathrm{abc}$ & $3.9 \mathrm{abcd}$ & $0.15 \mathrm{ab}$ & $2.9 \mathrm{~cd}$ \\
LU 644 & $28 \mathrm{bc}$ & $4.4 \mathrm{bcd}$ & $0.16 \mathrm{ab}$ & $2.8 \mathrm{bcd}$ \\
\hline LSD $(P<0.05)$ & 5.9 & 2.8 & 0.09 & 0.9 \\
\hline
\end{tabular}

a out of 40 seeds sown per pot

${ }^{b}$ where 1 = no evidence of disease and 5 = severely diseased (illustrated in Figure 1) Mean values followed by a different letter in the columns indicate significant differences according to Fisher's unprotected LSD test.

Table 7. Effect of nine Trichoderma isolates on seedling emergence (seed em.), and growth promotion in pathogen-free plant growth medium (data expressed as percentage of the control).

\begin{tabular}{llllllll}
\hline Isolate & \multicolumn{3}{c}{ Perennial ryegrass } & \multicolumn{2}{c}{ Red clover } & \multicolumn{2}{c}{ White clover } \\
\hline & Seed Em. & $\begin{array}{l}\text { Shoot } \\
\text { weight }\end{array}$ & $\begin{array}{l}\text { Root } \\
\text { weight }\end{array}$ & Seed Em. & $\begin{array}{l}\text { Shoot } \\
\text { weight }\end{array}$ & Seed Em. & $\begin{array}{l}\text { Shoot } \\
\text { weight }\end{array}$ \\
\hline LU 132 & -9 & 12 & 41 & -6 & 5 & 1 & 15 \\
LU 140 & -2 & 10 & 24 & 0 & 10 & $-11^{*}$ & -13 \\
LU 584 & 2 & $178^{*}$ & $100^{*}$ & 1 & $33^{*}$ & -3 & 34 \\
LU 633 & -8 & $172^{*}$ & $86^{*}$ & 0 & 2 & -2 & -24 \\
LU 634 & $-15^{*}$ & 33 & 78 & 3 & -6 & -1 & -22 \\
LU 740 & $-13^{*}$ & 10 & 2 & -5 & 12 & 2 & -12 \\
LU 713 & $-13^{*}$ & 36 & 23 & -8 & -8 & -1 & -8 \\
LU 540 & -9 & 4 & 18 & -6 & 19 & 0 & -1 \\
LU 644 & $-11^{*}$ & 25 & 28 & -1 & 15 & 0 & 11
\end{tabular}

*indicates a significant difference from the control at $P<0.05$ 
Table 8. Effect of application method of Trichoderma atroviride LU 584 on perennial ryegrass seedling emergence and fresh shoot weight in plant growth medium.

\begin{tabular}{llll}
\hline Treatment & Number of & \multicolumn{3}{l}{ Shoot weight } \\
& seedlings emerged & g/pot & g/plant \\
\hline Control (no Trichoderma) & $34.3 \mathrm{ab}$ & $10.3 \mathrm{a}$ & $0.30 \mathrm{a}$ \\
Wheat bran & $34.8 \mathrm{ab}$ & $14.3 \mathrm{~b}$ & $0.42 \mathrm{~b}$ \\
Seed coat & $33.6 \mathrm{a}$ & $10.6 \mathrm{a}$ & $0.31 \mathrm{a}$ \\
Granules & $36.2 \mathrm{~b}$ & $13.3 \mathrm{~b}$ & $0.37 \mathrm{ab}$ \\
\hline LSD $P<0.05$ & 2.093 & 2.0 & 0.07 \\
\hline
\end{tabular}

${ }^{a}$ out of 40 seeds sown per pot

798 Mean values followed by a different letter in the columns indicate significant differences according to Fisher's unprotected LSD test.

Table 9. Summary of seedling disease control activity against specific pathogens and growth promotion of three pasture species from nine Trichoderma isolates in a range of pot experiments.

\begin{tabular}{|c|c|c|c|c|c|c|}
\hline \multirow[t]{2}{*}{ Isolate } & \multicolumn{3}{|c|}{ Disease Control } & \multicolumn{3}{|c|}{ Growth Promotion } \\
\hline & R.s. $^{a}$ & S.t. ${ }^{b}$ & P.u. ${ }^{c}$ & P.r. ${ }^{d}$ & R.c. $^{e}$ & W.c. ${ }^{f}$ \\
\hline LU 132 (T. atroviride) & $++^{g}$ & + & $\mathrm{h}$ & + & & \\
\hline LU 140 (T. atroviride) & +++ & & & & & \\
\hline LU 584 (T. atroviride) & & & & +++ & ++ & ++ \\
\hline LU 633 (T. atroviride) & & + & + & +++ & & \\
\hline LU 634 (T. atroviride) & & +++ & & + & & \\
\hline LU 740 (T. hamatum) & & +++ & ++ & & & \\
\hline LU 713 (T. koningiopsi & & & & & & \\
\hline LU 540 (T. virens) & +++ & + & & & & \\
\hline LU 644 (T. viride) & & + & & & & \\
\hline
\end{tabular}




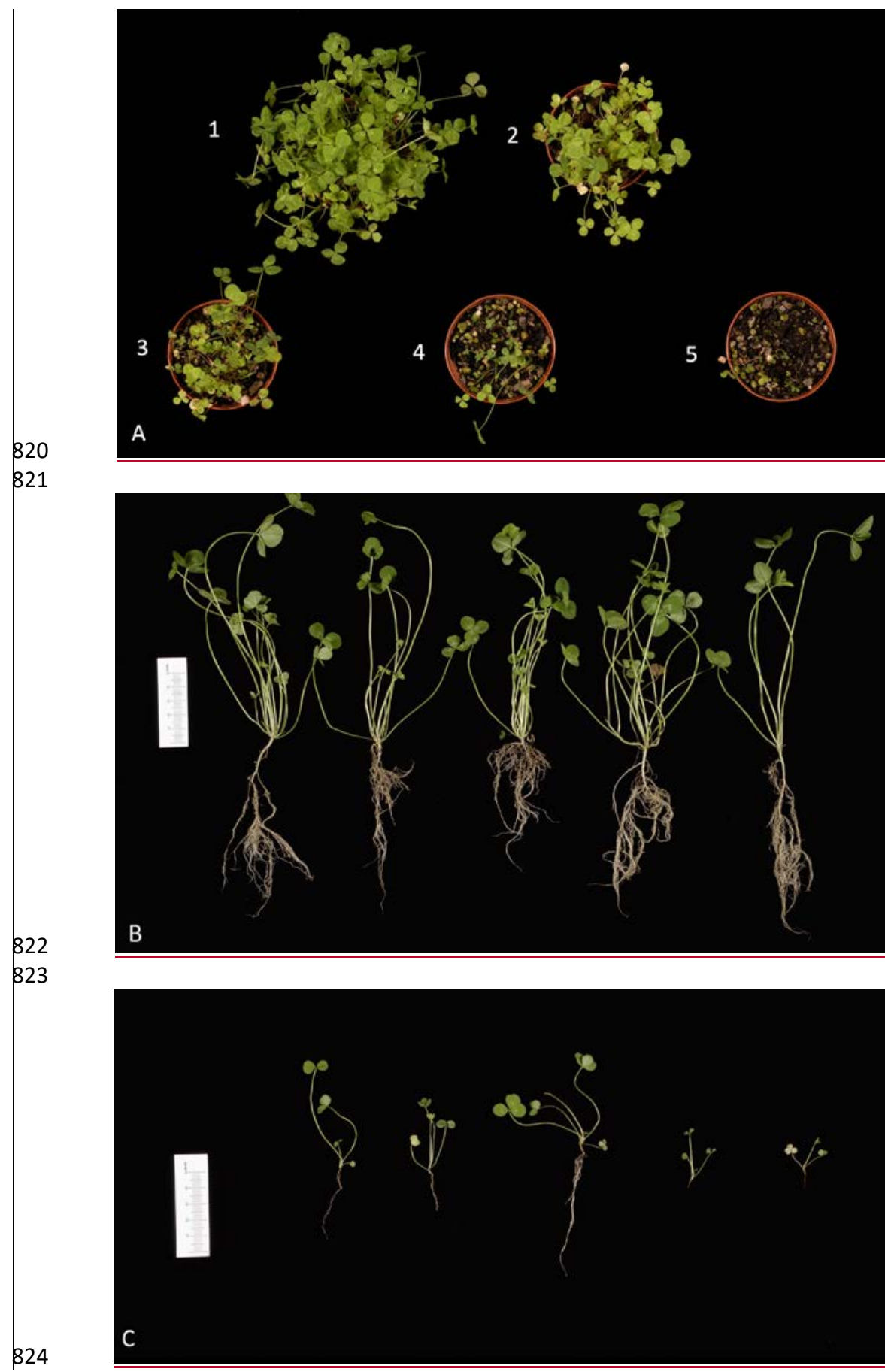

Formatted: Centered

Formatted: Centered

Formatted: Centered 
325 Figure 1 (A) Pythium ultimum disease score where 1=no symptoms evident and

$826 \underline{5}=$ =seedlings severely diseased; (B) five representative white clover plants with a

827 disease score of 1 ; (C) five representative white clover plants with a disease score of

828 4. Scale $=\overline{50 \mathrm{~mm}}$
Formatted: Font: Italic, Font color: Dark Red 